\title{
Öğretmenlerin Disiplini Sağlama Yaklaşımları ile Öğrencilerin Öğretimsel Muhalefet Davranışları Arasındaki İlişkinin İncelenmesi ${ }^{1}$
}

\author{
DOI: $10.26466 /$ opus. 855051
}

*

\author{
İsmet Kaya* - Hüseyin Fazlı Ergül ** \\ * Dr. Arş. Gör., Dicle Üniversitesi, Ziya Gökalp Eğitim Fakültesi, Diyarbakır/Türkiye \\ E-Posta:ismetkaya@dicle.edu.tr \\ ORCID:0000-0002-9998-1261 \\ ** Prof. Dr., Dicle Üniversitesi, Ziya Gökalp Eğitim Fakültesi, Diyarbakır/Türkiye \\ E-Posta:fazliergul@hotmail.com \\ ORCID:0000-0002-3966-677X
}

\section{Öz}

$B u$ araştırmada, lise öğrencilerinin algılarına göre öğretmenlerin disiplin yaklaşımlar ile öğretimsel muhalefet arasındaki ilişkiyi incelemek amaçlanmıştır. Öğrencilerin disiplin ve öğretimsel muhalefete ilişkin algıları arasındaki ilişki korelasyon analizi ile incelenmiştir. Araştırma sonucunda ulaşılan bazı bulgular şunlardır: Öğretmenlerin yüksek düzeyde çă̆daş disiplin anlayışına, orta düzeyde geleneksel disiplin anlayışına sahip oldukları tespit edilmiştir. Öğrencilerin öğretimsel muhalefet ile ilgili alt boyutlardaki algılarının ortalamaları; dışavurumcu için "orta düzeyde katılıyorum", etkileyici için "orta düzeyde katıllyorum" ve intikamcı için ise "hiç katılmıyorum" derecesinde saptanmıştır. Disiplin yaklaşımının "çă̆daş" alt boyutu ile öğretimsel muhalefetin "dışavurumcu" alt boyutu arasında negatif yönde "düşük" düzeyde bir ilişki; "etkileyici" alt boyutu ile pozitif yönde "orta" düzeyde anlamlı bir ilişki ve "intikamcı" alt boyutu ile negatif yönde "orta" düzeyde anlaml bir ilişki bulunmuştur. Disiplin yaklaşımının "geleneksel" alt boyutu ile öğretimsel muhalefetin "dışavurumcu" alt boyutu arasında pozitif yönde "düşük" düzeyde anlaml bir ilişki; "etkileyici" alt boyutu ile negatif yönde "düşük" düzeyde anlamlı bir ilişki ve "intikamcı" alt boyutu ile pozitif yönde "orta" düzeyde anlamlı bir ilişkinin olduğu saptanmiştır.

Anahtar Kelimeler: Disiplin yaklaşımı, muhalefet, öğretimsel muhalefet.

\footnotetext{
${ }^{1}$ Bu çalışma ismet Kaya'nın, H. Fazıı Ergül danışmanlığında Dicle Üniversitesi Eğitim Bilimleri Enstitüsü bünyesinde kabul edilen doktora tezinden üretilmiştir.
}

OPUS @ Uluslararası Toplum Araştırmaları Dergisi-International Journal of Society Researches ISSN:2528-9527 E-ISSN : 2528-9535

http://opusjournal.net 


\title{
The Relationship Between Discipline Approaches of Teachers and Students' Perceptions on Instructional Dissent
}

$*$

\begin{abstract}
The aim of this study is to examine the relationship between teachers' disciplinary approaches and instructional dissent according to the perceptions of high school students. Relational survey model was used in the research. The students' perceptions about disciplinary and instructional dissent were examined with correlation analysis. Important findings of the research are that: The students' perceptions for disciplinary approach are "often" in contemporary dimension, it is "sometimes" in traditional dimension. The average of students' perceptions of the sub-dimensions related to instructional dissent is "agree on a medium level" for expressionist, "agree on a medium level" for impressive, "never disagree" for revenge. The "contemporary" sub-dimension of disciplinary approach and "expressionist" sub-dimension of educational opposition have a relation in a negative direction and at a "low" level. The "contemporary" subdimension of disciplinary approach and "impressive" sub-dimension of instructional dissent have a significant relation in a positive direction and at a "medium" level. The "contemporary" sub-dimension of disciplinary approach and "vengeful" sub-dimension of instructional dissent have a significant relation in a negative direction and at a "medium" level. The "traditional" sub-dimension of disciplinary approach and "expressionist" sub-dimension of instructional dissent have a significant relation in a positive direction and at a "low" level. The "traditional" sub-dimension of disciplinary approach and "impressive" sub-dimension of instructional dissent have a significant relation in a negative direction and at a "low" level. The "traditional" sub-dimension of disciplinary approach and "vengeful" sub-dimension of instructional dissent have a significant relation in a positive direction and at a "medium" level.
\end{abstract}

Keywords: Disciplinary approach, dissent, instructional dissent 


\section{Giriş}

Okullarda öğrenme faaliyetinin istenilen düzeyde gerçekleştirilebilmesi için; öğrencilerin gereksinimlerinin karşılandığı, kendilerini iyi hissedebilecekleri, birtakım sorunlarından arındırılmış bir ortamın meydana getirilmesi gerekir (Uslu, 2002). Bu ortamın sağlanacağ 1 yer okuldaki öğretimin gerçekleştiği sınıflardır. Çünkü okuldaki öğretim daha çok sınıf ortamında gerçekleştirilmektedir. Sınıf, eğitim sisteminin en küçük ve en alt birimi olmasına rağmen, bu sistemin en önemli basamağını oluşturmaktadır (Sarıtaş, 2000, s.47). Eğitimin hedefi olan istendik yönde öğrenci davranışlarının oluştuğu ve şekillendiği yer büyük ölçüde sınıftır. Bu nedenle, davranışların kazanılmasında ve etkili öğrenmenin gerçekleşmesinde sınıf ortamının en iyi şekilde düzenlenmesi ve yönetilmesi gerekmektedir.

Sınıf yönetimi, etkili bir eğitim ve iletişim ağını gerçekleştirme amacına dönük etkinlikleri ifade eder. Bu anlamda sınıfı yönetmek, sınıf yönetimini etkileyen değişkenleri tanımayı gerektirmektedir (Aydın, 2014, s.19). Sınıf yönetimini etkileyen birçok değişken vardır. Bu değişkenler; sınıfın fiziksel düzeni, zaman yönetimi, davranış düzenlemeleri, planprogram etkinliklerinin düzenlenmesi, sınıfta ilişki ve iletişimin yönetimi, öğrenci motivasyonu, sınıf içi kuralların düzenlenmesi ve öğretmenlerin disiplin sağlama yaklaşımları şeklinde ifade edilebilir (Akan, 2015, s.9; Başar, 2004, s.4; Çelik, 2005, s.8-9; Demirtaş, 2012; Kılbaş Köktaş, 2003, s.3).

Bu değişkenlerden birisi olan disiplin sağlama yaklaşımı, sınıftaki öğrencilerin başarılarını arttırmada ve davranışlarını geliştirmede önemli bir işleve sahiptir (Gözütok, 1993; Akt. Şimşek, 2000). Çünkü sınıf yönetimi ve disiplin arasında sıkı bir ilişki bulunmaktadır. Hatta çoğu zaman bu iki kavram birbirinin yerine kullanılmaktadır. Sınıf yönetimi, öğretim sürecinin merkezinde yer almaktadır. Öğrenme, ancak uygun bir ortam oluşturulduğunda ve öğretim etkili bir şekilde planlanıp uygulandığında ortaya çıar. Planlanan ve uygulanan eğitim süreci de disiplin üzerine kurulmaktadır. Sınıfta disiplin sağlanmadan etkili bir öğrenmenin gerçekleşmesinden söz edilemez. Sınıftaki disiplin problemlerinin sonuçları, sınıf yönetimini doğrudan etkilemektedir (Bal, 2005, s.24). Bu nedenle 
sınıf yönetimi yaklaşımlarında özellikle disiplinin sağlanması konusuna ağırlık verilmiştir (Çelik, 2005, s.38).

İncelenen araştırmalardan ve kuramsal açıklamalardan yola çıkılarak, disiplin yaklaşımlarında iki temel bileşen üzerinde durulduğu söylenebilir. Bunlar, öğretmen ve öğrenci ilişkilerinin aşırı derecede yapılandırıldığı öğretmen merkezli "geleneksel yaklaşım" ile disiplini sağlamada gücü öğrencinin yararına olacak şekilde kullanan insancil, demokratik ve öğrenciyi merkeze alan "çağdaş yaklaşım" olarak isimlendirilebilir.

İnsancıl yaklaşımın savunucularından olan William Glasser (1969), Rudfolf Dreikurs (Dreikurs, Grunwald ve Pepper, 1982), John Neison (1987) ve Mortimer Adler (1990) çocukların gelişimi ve sosyal etkileşimleri gibi konular üzerinde durmuşlar ve çocukların kendi davranışlarını kontrol etme becerisi kazanmalarına yardımcı olacak araçlar, yöntemler geliştirmişlerdir. Davranışçı, öğretmeni merkeze alan yaklaşımlar: Skinner, Saul Axeirod (1977) ve Lee Canter (Canter, Canter, 1985) ceza ve ödüllerle çocukların davranışlarını yönlendirecek metodlar geliştirmişlerdir. Bu yaklaşımın amacı, belirlenen beklentilere göre çocukların davranışlarını yapılandırmaktır (Celep, 2004, s.170). Disiplin yaklaşımlarını davranışçı ve insancıl olarak ele aldığımızda, bu yaklaşımların hangisi benimsenirse, ona göre disiplin uygulamalarının şekillendiğini görürüz (Durukan, 2005). Bu yaklaşımlardan davranışçı yaklaşım, geleneksel yaklaşım olarak ve insancıl yaklaşım ise çağdaş yaklaşım olarak bilinmektedir.

Geleneksel anlayışla yönetilen bir sınıfta öğretmen, kendisinin hazırlayıp belirlediği birtakım kurallarla öğrencileri hizaya getirmeye ve bu kurallara herkesin harfiyen uymalarını sağlamaya çalışır. Öğretmen, öğrencilerin kurallara baş eğmelerini ister ve istediklerini öğrencilere nasıl yaptırabileceğine odaklanır (Saban, 2000, s.28). Bu yaklaşımda, öğrencinin ne istediğinden çok öğretmenin ne istediği önemli görülmektedir. Bu yaklaşım biçimi öğretmeni katı, müdahaleci ve otoriter yaparken, öğrenciyi de uysal, sorumluluk alamayan ve sürekli problem çıkarmaya hazır bir nesne haline getirmektedir.

Geleneksel yaklaşımın ilkeleri düzeni korumaya yöneliktir. Düzeni koruma, riski de beraberinde getirir. Çünkü düzen yönelimli öğretmen her an öğretimi kesebilir ve dersi tehlikeye sokabilir. Öğretmen en küçük istenmeyen davranışa karşı hoşgörülü değildir, hemen dersi kesip emir- 
ler yağdırabilir. Önemli olan sınıf düzenini sağlanmasıdır. Gerekirse öğrenci feda edilir. Çünkü düzen, eğitim ve öğretim etkinliklerinden daha önemli görülmektedir (Çelik, 2005: 10).

Öğrencinin birey olarak değerli olduğu felsefesinden hareket eden çağdaş disiplin yaklaşımı, demokratik, insancıl ve olumlu disiplin olarak da adlandırılır. Sınıf içi kuralları birlikte oluşturmak, öğrencilerin iyi alışkanlıklar kazanmalarına yardımcı olmak, örnek olmak, teşvik etmek, takdir etmek, beden dilini etkili kullanmak, davranışın altında yatan nedeni düşünmek, davranışın sonucunu açıklamak ve zararlarını fark etmesini sağlamak, küçük kusurları görmezden gelmek, 'sen dili' yerine 'ben dilini' kullanmak, etkin dinleme, dersi ve ortamı eğlenceli yapmak, sorun çözme becerisini kavratmak, öğrencinin kendi hatalı davranışlarını düzeltmesini sağlamak, veli-öğretmen-öğrenci toplantıları çağdaş disiplin uygulamalarına örnek olarak verilebilir (Kızılkaya, 2006, s.119).

Çağdaş yaklaşım, öğrencinin duygusal, düşünsel ve zihinsel gelişimine uygun insancıl bir modeldir. Burada eğitim-öğretim etkinliklerinin merkezinde öğrenci yer alır. Diğer bir ifadeyle, öğrenci sınıf yaşamının nesnesi değil, öznesidir. Sınıfta uyulması gereken kurallar, öğretim yöntemleri, dersin amaçları gibi etkinlikler birlikte tartışılarak belirlenir (Aydın, 2014, s.6). Çağdaş yaklaşıma göre, sınıf yönetiminin merkezinde öğrenci bulunur. Bu yaklaşımda otorite yerine etkileşim esas alınmıştır (Ünal ve Ada, 2000, s.31). Sınıfta etkinlik ve sorumluluklar paylaşılmıştır. Karar alma sürecinde öğretmen sadece lider, rehberlik ve yardım edendir. Öğretmen patron konumunda değil, sınıfın herhangi bir üyesi gibidir.

Birey ve çevre arasındaki ilişki, öğrencilerin davranışlarını açıklamaya yönelik yapılan tüm tartışmaların altını çizdiği temel değişkendir. Bu ilişkiyi şekillendiren ise bireylerin inançlarını, davranış biçimlerini, değer yargılarını ve varsayımlarını içeren kültürel yapıdır. Bu kültürel yapı önce aileden daha sonra sınıftan başlayıp topluma uzanan bir hiyerarşiyi kapsar. Bu anlamda, disiplin sürecinde öğrencilerin sınıf kurallarını anlamlandırma ve tanımlamada (Cheng, 2000) bu kuralların, nasıl yorumlandığı, sınıftaki uygulamaların öğrenciler tarafından nasıl değerlendirildiği önem arzetmektedir (Neff ve Helwing, 2002). Sınıf deneyimlerine dayanan bu olumsuz reaksiyonların bir türü kural ve uygulamalarla 
ilgili uyuşmazlığın ifadesi veya fikirlerin tutarsızlığı da denilebilecek bir muhalefet şeklinde olabilir (Kassing, 1997).

İdeal olarak sınıf ortamı öğrenmeyi teşvik eden, öğretmen ile öğrenci arasında etkili ve uygun iletişimi düzenleyen bir ortamı ifade eder. Fakat öğrencilerin beklentileri öğretmen tarafından karşılanmayabilir ve bu durum değişik şekillerde öğrencilerin muhalefet etmesine neden olabilir. Öğrencilerin; öğretmenlerin disiplini sağlama davranışları ve bununla ilişkili diğer etkenlere yönelik, hoşnutsuzluğunu ve şikâyetlerini dile getirdikleri bu muhalefet biçimine öğretimsel muhalefet denir (Goodboy, 2011; Goodboy ve Martin, 2014).

Öğretimsel muhalefet, çoğunlukla öğretmenin hoş olmayan tutum ve sınıfta aldığı haksız kararlardan oluşan etkisiz bir öğretimden kaynaklı öğrenci algısının verdiği bir yanıt olarak meydana çıkmaktadır. Öğrenciler öğretimsel muhalefetlerini ifade ederken genellikle sınıfla ilgili konularda anlaşmazlıkları ve şikâyetleri dile getirirler (Goodboy, 2011a). Öğretmenler anlaşılır, akıcı, fark edilebilir etkili davranışlar sergilediklerinde ve olumlu bir sınıf ortamı oluşturduklarında öğretimsel muhalefetten vazgeçilmektedir (LaBelle, Martin ve Weber, 2013). Yapılan araştırmalarda, öğretmenlerin sergiledikleri olumsuz davranış şeklinin öğrencilerin derslere katılımını azalttığ (Goodboy ve Bolkan, 2009), öğretmenleri ile iletişime geçmek için gerekli olan motivasyonu düşürdügü (Goodboy, Myers ve Bolkan, 2010), daha az duyuşsal ve bilişsel öğrenme sağladığ (Banfield, Richmond ve McCroskey, 2006; Goodboy ve Bolkan, 2009) görülmektedir. Dahası uygun davranış sergilemeyen ve olumlu bir sınıf iklimi oluşturamayan öğretmenlerin, daha çok yorulduklarl, daha az sevildikleri (Can ve Baksi, 2014), daha az güvenilir (Banfield vd., 2006; Thweatt ve McCroskey, 1998) ve daha az duyarlı (Wanzer ve McCroskey, 1998) oldukları saptanmıştır. Ayrıca öğretmenlerin yetersiz, zayıf ve saldırgan olduğu sınıf ortamında öğrenciler öğretmenleri daha az pozitif bulmakta ve bu öğrencilerin öğrenme eğilimi daha az olmaktadır (Vallade ve Myers, 2014).

Goodboy, öğrencilerin muhalefet etme nedenleri ve şekilleri üzerinde yaptığı çalışmalarda, öğrencilerin üç muhalefet türünü kullandıklarını keşfetmiş̧ir. Bunlar; Dişavurumcu (expressive), etkileyici (rhetorical), intikamcı (vengeful) muhalefettir. Dışavurumcu ve intikamcı muhalefet öğrencilerin iletişimini, motivasyonlarını, duyuşsal öğrenimlerin ve sınıf 
adaleti algılarını olumsuz etkiler. Etkileyici muhalefet ise öğretmen ile kurulan iletişim sayesinde bir yanlışı düzeltmeye yönelik tek muhalefet türüdür ve bilişsel öğrenmeye pozitif etkisi vardır (Goodboy, 2011a). Ayrıca öğretmenlerin anlayışlı oldukları hissedildiğinde öğrenciler daha çok etkileyici muhalefeti az da olsa dişavurumcu muhalefeti kullanmaktadirlar (LaBelle, Martin ve Weber, 2013).

Dişavurumcu muhalefet, öğrencinin, kendi duygusal durumunu iyileştirmek için duygularını açığa vurma ve ifade etme isteğidir. Dışavurumcu muhalefet, öğrencinin başka bir gruba giderek empati ve/veya sempati kazanmak için hayal kırıklığını dile getirmesi durumunda gerçekleşir (örneğin öğrencinin zor bir sınavı başka bir öğrenciye yakınması gibi) (Goodboy, 2011b). Dışavurumcu muhalefet, sınıftaki bir anlaşmazlık durumunda duygularını ve hayal kırıklıklarını açıkça ortaya koyan öğrenciler tarafından kullanılmaktadır. Öğrenciler öncelikle kendilerini daha iyi hissetmek için dışavurumcu muhalefeti kullanırlar ve bu mesajları sınıf arkadaşlarına, ailelerine ve arkadaşlarına iletirler.

Etkileyici muhalefet, öğretmenle kurulan iletişim ile bir yanlışı düzeltmeye yönelik tek muhalefet türüdür ve bilişsel öğrenmeye pozitif etkisi vardır (Goodboy, 2011a). Etkileyici muhalefeti kullanan öğrenciler vicdani bir sorumluluk duygusu ile hareket ederek sınıf içinde kendi kanaatleri doğrultusunda uygun olmayan düşünce ve uygulamalara karşı çıkmakta ve bulunduğu sınıfı daha iyi bir yer yapmak için muhalefet mesaji vermektedir.

İntikamcı muhalefet, itibarına leke düşürerek bir öğretmenden intikam almak maksadıyla onun hakkında olumsuz söylemleri yaymakla gerçekleşir. Örneğin bir öğretmeni meslektaşlarıyla zor durumda bırakmaya çalışmak, gelecekte öğrencilerin o öğretmenin dersini almamalarını ve/veya öğretmenin hata diye algılanan yanlışından dolayı kendi mesleğini kaybetmesini sağlamaya çalışmaktır (Goodboy, 2011b). İntikamc1 muhalefet; öğretmene misilleme veya öç alma yoluyla yapılmaktadır. Öğrenciler öğretmenlerini sıkıntıya sokmak için (öğretmenlerini işten kovdurmaya sebebiyet ihtimali dâhil) ve diğer öğrencilerin aynı problemlerle karşı karşıya gelmelerini önlemek ve diğer eğitimcilerin sorunlu bir meslektaşa sahip olduklarının farkına varmalarını sağlamak için öğretmenlerinin itibarını yerle bir etmek için muhalif olduklarını belirtmektedirler. İntikamcı muhalefet, öğrencilerin kendilerini yararsız-işe yara- 
maz hissettiklerinde sınıfta kendilerince eşitliği (dengeyi) sağlamak için başvurdukları muhalefet türüdür.

Ülkemizde alan yazında çoğunlukla öğrencilerin disiplinsiz ve istenmeyen davranışları üzerinde durulurken, öğretimsel muhalefet davranışları üzerinde yapılan çalışmalara rastlanmamıştır. Oysaki etkili öğrenmenin sağlandığı sınıf ortamlarının, öğrencilerin arkadaşları ve öğretmenleri ile iyi ilişkiler kurduğu ortamlar olduğunu söylemek mümkündür. Bu nedenle, öğrencilerin öğretimsel muhalif davranışlarının anlaşılması sınıflardaki iletişim yapısının çözümlenmesine yardım etmesi bakımından önemlidir. Okullarda öğrencilerin öğretimsel muhalifet davranışlarını tetikleyen nedenlerin, muhalif davranış biçimlerinin ve sergiledikleri muhalefetin yol açtı̆̆ 1 sonuçların saptanması gerek okul gerekse öğretmenler bakımından önem taşımaktadır. Öncelikle öğrencileri muhalefet etmeye iten koşulların mevcut oluşu, genelde okullarda özelde ise sınıflarda bazı sorunların yaşandığının bir göstergesi olarak düşünülebilir. Bu bakımdan öğrencileri muhalefet etmeye iten nedenlerin irdelenmesi ve çözümlenmesi; okul içi sorunların teşhis edilmesine ve bu sorunlara dönük iyileştirme ve geliştirme çalışmalarının yapılmasına 1şık tutması açısından önemli görülmektedir.

Öğretimsel muhalefet, araştırma için nispeten yeni bir alan olduğu için öğrencilerin muhalefet deneyimlerini etkileyebilecek birçok faktör ve değişken vardır. Öğretmenlerin kullandıkları disiplin sağlama yaklaşımlarının karşılaştırıldığı (Çelikkaleli ve İnandı, 2012; Sağnak, 2007), buna ilişkin yönetici ve öğretmen görüşlerinin alındığı (Aydın, 2004; Bilir, Kuru ve Tezcan, 2007) ve disiplin anlayışlarının incelendiği (Sesli ve Bozgeyikli, 2015) birçok çalışma bulunmaktadır. Ancak öğretmenlerin kullandıkları disiplin yaklaşımları ile öğrencilerin öğretimsel muhalefet algıları arasındaki ilişkiyi belirlemeye yönelik literatürde herhangi bir araştırmaya rastlanmamıştır. Bu araştırma, özellikle öğretimsel muhalefet ile yakından ilgili olduğu düşünülen öğretmenlerin disiplini sağlama yaklaşımlarının öğretimsel muhalefet değişkeniyle incelenmesinden ötürü önemlidir. Bu çalışma, disiplin ve öğretimsel muhalefet alanlarında günümüzde yaşanan ve ortaya çıan problemlere çözüm önerileri geliştirmeye yöneliktir. Araştırmanın amacı, Anadolu lisesi öğrencilerinin algılarına göre öğretmenlerin disiplin yaklaşımları ile öğrencilerin öğretimsel muhalefet davranışları arasındaki ilişkiyi incelemektir. 
$\mathrm{Bu}$ amaç doğrultusunda aşağıdaki sorulara yanıt aranmıştır.

1. Anadolu lisesi öğrencilerinin, öğretmenlerin kullandıkları disiplin yaklaşımlarına ilişkin algıları nasıl bir dağılım göstermektedir?

2. Anadolu lisesi öğrencilerinin öğretimsel muhalefet davranışları nasıl bir dağılım göstermektedir?

3. Anadolu lisesi öğrencilerinin algılarına göre öğretmenlerin kullandıkları disiplini sağlama yaklaşımları ile öğretimsel muhalefet davranışları arasında anlamlı bir ilişki var mıdır?

Bu araştırma, 2017-2018 eğitim-öğretim yılında Diyarbakır merkez ilçelerdeki Anadolu liselerinde öğrenim gören öğrenciler (Anadolu meslek liseleri ve Anadolu imam hatip liseleri hariç) ile sinırlıdır.

$\mathrm{Bu}$ araştırmanın verileri, öğrencilere uygulanan ölçek maddeleri ile sinirlıdır.

\section{Yöntem}

$\mathrm{Bu}$ araştırmada, nicel araştırma yöntemlerinden ilişkisel tarama modeli kullanılmıştır. İlişkisel tarama modeli iki ve daha çok sayıdaki değişken arasında birlikte değişim varlığını ve/veya derecesini belirlemeyi amaçlayan araştırma modelidir (Karasar, 2005, s.79-81). Buna göre öğretmenlerin kullanmış oldukları disiplin sağlama yaklaşımlarının, lise öğrencilerinin öğretimsel muhalefet algılarını anlamlı bir biçimde yordayıp yordamadığı incelenmiştir. Bunu belirlemek amacıyla ilişkisel araştırma desenlerinden yordama araştırması kullanılmıştır.

\section{Evren ve Örneklem}

Araştırmanın evreni, 2017-2018 eğitim-öğretim yılında Diyarbakır merkez ilçelerinde (Bağlar, Kayapınar, Sur, Yenişehir) bulunan 19 Anadolu Lisesinde (Meslek ve Teknik Anadolu liseleri hariç) öğrenim gören 16.795 ortaöğretim öğrencisinden oluşmaktadır. Araştırmanın evreni ile ilgili veriler Diyarbakır İl Milli Eğitim Müdürlüğü'nün istatistiklerine dayalı olarak tespit edilmiştir. Evreni oluşturan öğrencilerin ilçe ve okullara göre dağılımına bakıldığında yedi okulun bazı şubelerinde hiç öğrenci olmadığı için bu okullar örneklem dışında tutulmuştur. 
Araştırmanın örneklemini belirlemek için öncelikle Diyarbakır merkez ilçelerinde bulunan Anadolu liselerinde öğrenim gören öğrencilerin sayılarından yola çıkılarak tabakalı örnekleme yöntemi kullanılmıştır. Bu yöntem sınırları saptanmış bir evrende alt tabakalar veya alt birim gruplarının var olduğu durumlarda kullanılmaktadır (Yıldırım ve Şimşek, 2005). Tabakalı örnekleme, evrenin, araştırmacının bağımlı değişkeni üzerinde etkisi olabilecek şekilde homojen olmadığı durumlarda tercih edilebilecek bir yöntemdir. Evrenden seçilen tabakaların büyüklükleri farklıysa ve bunun da araştırmaya yansıması gerekiyorsa, alt evrenden örnekleme alınacaklar, her bir alt evrenin evren içindeki oranınca belirlenir (Can, 2016). Bu araştırmanın örneklemi 3 basamakta belirlenmiştir.

İlk aşamada, okullardaki 9. sınıf, 10. sınıf, 11. sınıf ve 12. sınıf şubelerinin her biri tabaka olarak örnekleme alınmıştır. Şubelerdeki öğrenci sayıları dikkate alınarak tabakalar oluşturulmuştur. Örneklem seçimi işleminde, Örneklem Büyüklükleri Tablosu'ndan (Ek-1) yararlanılmış ve araştırmanın örneklemini $\alpha=.05$ anlamlılık düzeyinde 381 öğrencinin temsil edebileceği varsayılmıştır (Anderson, 1990; Akt. Balcı, 2015, s.108.). Ancak uygulama sırasında karşılaşılabilecek sorunlar ve veri kaybı da göz önünde bulundurularak Anadolu liselerinde öğrenim görmekte olan 1.500 öğrencinin örnekleme alınması kararlaştıılmıştır. Örneklem sayısı belirlendikten sonra, ulaşılması gereken öğrenciler belirlemek amacıyla sırasıyla tabakalama, oranlama ve rastgele seçme işlemleri uygulanmıştır. Tüm şubeler için şubedeki öğrenci sayısının evrende temsil ettiği oran hesaplanmış ve bu oran dikkate alınarak her bir şubede ulaşılacak öğrenci sayısı belirlenmiştir. Oranlamanın yapılma sebebi örneklem dağılımını evrenin dağılımına mümkün olduğunca benzeştirmek içindir. Bu sayının evren içindeki tabakaların dağılımına uygun olmasını sağlamak için her bir şubenin evrene oranından faydalanarak her bir şubeye ait örneklem büyüklüğü belirlenmiştir;

Şubedeki örneklem büyüklüğü= 1500 x Şubedeki öğrenci sayısi/Evren Örneğin; Birlik Anadolu Lisesinin lise 1 şubesinde 289 öğrenci bulunmaktadır. Buna göre Birlik Anadolu lisesinde ulaşılması gereken lise 1 öğrenci sayısı şu şekilde hesaplanmıştır; Öğrenci sayısı $=1.500 \mathrm{x}$ 289/16.701= 25.95 şeklinde hesaplanarak, sonuç tam sayıya yuvarlanmış ve 26 öğrenciye ulaşılmıştır. Diğer şubelerdeki örneklem belirleme yön- 
temi de aynı şekilde hesaplanmıştır. Aşağıdaki tabloda Anadolu liseleri ve bu liselerin şubelerinde ulaşılan öğrenci sayıları verilmiştir.

Tablo 1. Okullarda Bulunan Şubeler ve Bu Şubelerden Örnekleme Alınan Öğrenci Sayılan

\begin{tabular}{|c|c|c|c|c|c|c|c|c|}
\hline \multirow[t]{2}{*}{ İLÇE/OKUL ADI } & \multirow{2}{*}{$\begin{array}{c}\text { 9. Sinıf } \\
\text { Öğrenci } \\
\text { Sayısı }\end{array}$} & \multirow{2}{*}{$\begin{array}{c}\text { 10. Sinıf } \\
\text { Öğrenci } \\
\text { Sayısı }\end{array}$} & \multirow{2}{*}{$\begin{array}{c}\text { 11. Sinıf } \\
\text { Öğrenci } \\
\text { Sayısı }\end{array}$} & \multirow{2}{*}{$\begin{array}{c}\text { 12. Sinıf } \\
\text { Öğrenci } \\
\text { Sayısı }\end{array}$} & \multicolumn{4}{|c|}{ Örneklem Sayısı } \\
\hline & & & & & 9. Sinif & $\begin{array}{c}10 . \\
\text { Sinıf }\end{array}$ & $\begin{array}{c}11 . \\
\text { Sinif }\end{array}$ & $\begin{array}{c}12 . \\
\text { Sinif } \\
\end{array}$ \\
\hline Birlik Anadolu Lisesi & 289 & 273 & 204 & 301 & 26 & 25 & 18 & 27 \\
\hline Güler Şevki Özbek Anadolu Lisesi & 241 & 80 & 158 & 124 & 22 & 7 & 14 & 11 \\
\hline $\begin{array}{l}\text { Necip Fazıl Kısakürek Anadolu } \\
\text { Lisesi }\end{array}$ & 157 & 129 & 430 & 626 & 14 & 12 & 39 & 56 \\
\hline Ali Emiri Anadolu Lisesi & 355 & 260 & 244 & 143 & 32 & 23 & 22 & 13 \\
\hline $\begin{array}{l}\text { Fatih Sultan Mehmet Anadolu } \\
\text { Lisesi }\end{array}$ & 319 & 202 & 243 & 206 & 29 & 18 & 22 & 19 \\
\hline Alparslan Anadolu Lisesi & 119 & 198 & 68 & 80 & 11 & 18 & 6 & 7 \\
\hline $\begin{array}{l}\text { 80. Yil Cumhuriyet Anadolu } \\
\text { Lisesi }\end{array}$ & 104 & 71 & 89 & 151 & 9 & 6 & 8 & 14 \\
\hline $\begin{array}{l}\text { 85. Yıl Milli Egemenlik Anadolu } \\
\text { Lisesi }\end{array}$ & 172 & 162 & 131 & 238 & 15 & 15 & 12 & 21 \\
\hline Ahmet Arif Anadolu Lisesi & 200 & 284 & 744 & 170 & 18 & 26 & 67 & 15 \\
\hline Diyarbakir Anadolu Lisesi & 148 & 155 & 163 & 303 & 13 & 14 & 15 & 27 \\
\hline Gaffar Okkan Anadolu Lisesi & 162 & 79 & 137 & 292 & 15 & 7 & 12 & 26 \\
\hline Nevzat Ayaz Anadolu Lisesi & 196 & 166 & 170 & 253 & 18 & 15 & 15 & 23 \\
\hline Orhan Asena Anadolu Lisesi & 200 & 429 & 738 & 66 & 18 & 39 & 66 & 6 \\
\hline Rekabet Kurumu Anadolu Lisesi & 169 & 166 & 172 & 222 & 15 & 15 & 15 & 20 \\
\hline $\begin{array}{lll}\text { Selahaddini } & \text { Eyyubi } & \text { Anadolu } \\
\text { Lisesi } & & \\
\end{array}$ & 230 & 135 & 152 & 333 & 21 & 12 & 14 & 30 \\
\hline Sezai Karakoç Anadolu Lisesi & 120 & 160 & 162 & 189 & 11 & 14 & 15 & 17 \\
\hline $\begin{array}{l}\text { Şehit Süleyman Sorkut Anadolu } \\
\text { Lisesi }\end{array}$ & 281 & 383 & 190 & 90 & 25 & 34 & 17 & 8 \\
\hline Yeni Diyarbakır Anadolu Lisesi & 275 & 245 & 242 & 109 & 25 & 22 & 22 & 10 \\
\hline Ziya Gökalp Anadolu Lisesi & 190 & 450 & 219 & 195 & 17 & 40 & 20 & 18 \\
\hline Genel Toplam & 3927 & 4027 & 4656 & 4091 & 354 & 362 & 419 & 368 \\
\hline
\end{tabular}

Tablo 1'de görüldüğü üzere liselerin tüm şubelerinden ulaşılan öğrenci sayıları verilmiştir. Buna göre Birlik Anadolu lisesinin 9. sınıf şubesinde okumakta olan 289 öğrenciden 26 'sına, 10. sinıf şubesinde okumakta olan 273 öğrenciden 25'ine, 11. sınıf şubesinde okumakta olan 204 öğrenciden 18 'ine ve 12. sinıf şubesinde okumakta olan 289 öğrenciden 27'sine ulaşılmıştır. Diğer liselerin de şubelerinde ulaşılan öğrenci sayıları bu şekilde tabloda verilmiştir. 
Son aşamada, okullardaki şubeler basit örnekleme yöntemi ile belirlenmiştir. Basit örnekleme yöntemi, "oluşturulan evren listesinden örnekleme birimlerinin seçkisiz olarak çekilmesi" olarak tanımlanmaktadır (Büyüköztürk, Kılıç-Çakmak, Akgün, Karadeniz ve Demirel, 2014). Herbir sınıf düzeyinde basit yöntemle seçilen şubelerin öğrenci listelerinde yer alan tüm öğrenciler örnekleme dâhil edimiştir. Örneğin Birlik Anadolu lisesinde 8 tane 9. sınıf şubesi bulunmaktadır. Bu sınıflar içerisinden toplamda 26 öğrenciye ulaşılması gerekmektedir. Bu lisenin 9. sınıf şubesinden 2 şube basit örnekleme yöntemi ile seçilmiş daha sonra bu 2 şubedeki bütün öğrencilere ölçek formları uygulanmıştır. Veri kaybını engellemek amacıyla bu şubede eksiksiz doldurulan anket formlarından 26 tanesi rastgele seçilerek örnekleme dâhil edilmiştir. Bu yolla toplam 1512 ölçek formu değerlendirmeye alınmıştır.

\section{Veri Toplama Araçları}

Araştırmada veri toplama aracı olarak iki farklı ölçme aracı kullanılmıştır.

Disiplin Yaklaşımları Ölçeği'nin (Kaya, Ergül ve Aküzüm, 2018), yapı geçerliğinin, açımlayıcı (AFA) ve doğrulayıcı (DFA) faktör analizleri ile değerlendirildiği görülmüştür. Yapılan AFA sonucunda KMO değeri 0,94; Barlett Sphericity testi sonucu ise anlamlı ( $\mathrm{p}<.05, \mathrm{df}=231)$ bulunmuştur. Ölçek 39 madde olup, 39 maddeden 19 madde (1-19) I. faktör olan çağdaş yaklaşımı, 20 madde (20-39) II. faktör olan geleneksel yaklaşımı oluşturmaktadır. Ölçekte ters kodlanan madde yer almamaktadır. I. faktördeki maddelerin faktör yüklerinin 0,40-0,69; II. faktördeki maddelerin faktör yüklerinin ise 0,54-0,73 arasında değiştiği saptanmıştır. Açıklanan toplam varyans $\% 44,90$ olarak belirlenmiştir.

Bu araştırmada kullanılan Disiplin Yaklaşımları Ölçeği iki bölümden oluşmaktadır: I. bölümde kişisel bilgilerle ilgili yedi, II. bölümde ise disiplin yaklaşımları ile ilgili 39 madde yer almaktadır. Kişisel bilgiler hariç, 39 maddeden oluşan veri toplama aracındaki soruların cevap seçenekleri ve bu seçeneklere verilen değerler; "Asla (1), Nadiren (2), Bazen (3), Çoğunlukla (4) ve Her Zaman (5)" puan olarak belirlenmiştir. 
Tablo 2. Disiplin Yaklaşımları Ölçeği'nin İç Tutarlılık Katsayısına İlişkin Bulgular

\begin{tabular}{llll}
\hline Boyut & Madde sayısı & $\begin{array}{l}\text { Ölçeği geliştirenin } \\
\text { sonuçları }\end{array}$ & $\begin{array}{l}\text { Bu araştırmada elde edilen } \\
\text { sonuç }\end{array}$ \\
\hline Çağdaş & 19 &, 91 &, 91 \\
Geleneksel & 20 &, 94 &, 92 \\
Toplam & 39 &, 95 &, 74 \\
\hline
\end{tabular}

Öğrencilerin öğretimsel muhalefet algılarını ölçmek için “Instructional Dissent Scale" adıyla Goodboy (2011a) tarafından geliştirilen ve Türçeye Öğretimsel Muhalefet Ölçeği adıyla Dağlı, Ergül ve Kaya (2017) tarafından uyarlanan ölçek kullanılmıştır. Öğretimsel muhalefet ölçeği "dışavurumcu muhalefet", "etkileyici muhalefet" ve "intikamcı muhalefet" olmak üzere üç alt boyut ve 22 maddeden oluşmaktadır. Her bir boyutta bulunan madde sayıları; dişavurumcu muhalefet 10 madde $(1,2$, $3,4,5,6,7,8,9,10)$, etkileyici muhalefet 6 madde $(11,12,13,14,15,16)$ ve intikamcı muhalefet ise yine 6 madde $(17,18,19,20,21,22)$ şeklindedir. Ölçekte tersten puanlanan madde yoktur. Türkçe formda tüm maddeler özgün ölçekteki alt faktörlerle uyumlu olarak bulunmuştur ve özgün formun üç faktörlü yapısı oluşmuştur. Ayrıca Öğretimsel Muhalefet Ölçeği'nin faktör yük değerlerinin dişavurumcu muhalefet alt boyutunda .39 ile .73 arasında, etkileyici muhalefet alt boyutunda .60 ile .75 arasinda ve intikamcı muhalefet alt boyutunda ise .63 ile .83 arasında değiştiği bulgulanmıştır.

Ölçek 5'li likert tipi bir ölçek olup; Tamamen Katıllyorum (5), Büyük Oranda Katılıyorum (4), Orta Düzeyde Katılıyorum (3), Çok Az Katılıyorum (2), Hiç Katılmıyorum (1) dereceleme düzeyleri ile puanlanmaktadir. Ters kodlanan madde yoktur.

Araştırmanın alt amaçlarından olan ve bağımsız değişkenler ile boyutlar arasında anlamlı farkın olup olmadığını belirlemek için yapılan anlamlılık testlerinde öncelikle parametrik varsayımlardan olan verilerin normalliği test edilmiştir.

Tablo 3. Öğretimsel Muhalefet Ölçeği'nin İç Tutarlllık Katsayısına İliş̧kin Bulgular

\begin{tabular}{llll}
\hline Boyut & Madde sayısı & $\begin{array}{l}\text { Ölçeği geliştirenin so- } \\
\text { nuçları }\end{array}$ & $\begin{array}{l}\text { Bu araştırmada elde edilen } \\
\text { sonuç }\end{array}$ \\
\hline Dışavurumcu & 10 &, 73 &, 83 \\
Etkileyici & 6 &, 81 &, 86 \\
İntikamcı & 6 &, 84 &, 90 \\
Toplam & 22 &, 80 &, 84 \\
\hline
\end{tabular}


Araştırmada elde edilen veriler normal dağılım gösterdiğinden dolayı parametrik testler kullanılmıştır. Veri setinin normal dağılım gösterdiği belirlendikten sonra disiplin yaklaşımları, sınıf iklimi ve öğretimsel muhalefet arasındaki ilişkiler Pearson Momentler Çarpım Korelâsyonu ile incelenmiştir.

\section{Bulgular}

Araştırmaya katılan öğrencilerin, öğretmenlerin kullandıkları disiplin yaklaşımlarına ve öğretimsel muhalefete ilişkin görüşlerinin nasıl bir dağılım gösterdiğini belirlemek için ölçme aracındaki tüm maddelere verilen cevapların madde ortalamaları, standart sapmaları, boyut ortalamaları ve düzeyleri hesaplanmış ve sonuçlar Tablo 4 'te verilmiştir.

Tablo 4. Öğretmenlerin Kullandıkları Disiplin Yaklaşımlarına İlişkin Öğrenci Görüşlerine Ait Betimsel Analiz Sonuçları

\begin{tabular}{lccl}
\hline & $\bar{X}$ & Ss & Düzey \\
\hline Çağdaş Disiplin Yaklaşımı & 3,50 & 0,68 & Çoğunlukla \\
Geleneksel Disiplin Yaklaşımı & 2,59 & 0,78 & Nadiren \\
\hline
\end{tabular}

Tablo 4'te görüldüğü gibi, öğrenciler, öğretmenlerin kullandıkları disiplin yaklaşımının "çağdaş" alt boyutunda en çok "Öğretmenlerimiz öğrenciye ismi ile hitap eder." ( $\bar{X}=4,17)$ ifadesine "Çoğunlukla" düzeyinde, en az ise "Öğretmenlerimiz istenen davranışları sergileyen öğrencileri ödüllendirir." ( $\bar{X}=2,58)$ ifadesine "Nadiren" derecesinde görüş belirtmişlerdir. Öğrenciler ilgili alt boyuta $(\bar{X}=3,50)$, “Çoğunlukla" düzeyinde görüş belirtmişlerdir. Buna göre öğrenciler, öğretmenlerinin çağdaş disiplin anlayışına sahip oldukları görüşüne sahiptir.

Öğrenciler, öğretmenlerin kullandıkları disiplin yaklaşımının "geleneksel" alt boyutunda en çok "Öğretmenlerimiz öğrenciyi düşük not vermekle tehdit eder." ( $\bar{X}=3,13$ ) ifadesine "Bazen" düzeyinde, en az ise "Öğretmenlerimiz sınıf kurallarına uyulmadığında ceza verir (dayak atma, azarlama, konuşmama vb.)" ( $\bar{X}=2,08)$ ifadesine "Nadiren" düzeyinde görüş belirtmişlerdir. Katılımcllar ilgili alt boyuta $(\bar{X}=2,59)$ “Na- 
diren" şeklinde görüş belirtmişlerdir. Geleneksel disiplin boyutundaki maddeler dikkate alındığında öğretmenlerin nadiren çağdaş disiplin yaklaşımına aykırı olan geleneksel birtakım davranışlar sergiledikleri de görülmektedir. Buna göre öğretmenler çağdaş bir disiplin anlayışına sahip olmakla birlikte nadiren de olsa geleneksel bir yaklaşım sergileyebilmektedirler.

Tablo 5. Öğretimsel Muhalefete İlişkin Öğrenci Görüşlerine Ait Görüşlerine Ait Betimsel Analiz Sonuçları

\begin{tabular}{lccl}
\hline Maddeler & $\bar{X}$ & Ss & Düzey \\
\hline Dışavurumcu Boyut Ortalaması & 3,12 &, 77 & Orta Düzeyde Katıllyorum \\
Etkileyici Boyut Ortalaması & 3,23 &, 97 & Orta Düzeyde Katıllyorum \\
İntikamcı Boyut Ortalaması & 1,75 &, 97 & Hiç Katılmıyorum \\
\hline
\end{tabular}

Tablo 5'te görüldüğü üzere, öğrenciler, öğretimsel muhalefetin “dışavurumcu" alt boyutunda en çok "Beni kızdıran öğretmen hakkında sınıftaki diğer öğrencilerin de şikâyetleri olup olmadığını öğrenmek için onlarla konuşurum" ( $\bar{X}=3,71$ ) ifadesine "büyük oranda katıllyorum" düzeyinde, en az ise "Kızgınlığımı dindirmek için öğretmenimden şikâyetçi olurum" ( $\bar{X}=1,97)$ ifadesine "çok az katıliyorum" derecesinde görüş belirtmişlerdir. Öğrenciler ilgili alt boyuta $(\bar{X}=3,12)$, “orta düzeyde katılıyorum" düzeyinde görüş belirtmişlerdir. Buna göre öğrenciler; öğretmenlerini arkadaşlarına şikâyet etmek, öğretmenlerinin dedikodusunu yapmak ve dersle ilgili sıkıntılarını başkalarıyla paylaşmak gibi dışavurumcu muhalefet davranışlarını orta düzeyde sergilemektedirler.

Öğrenciler, öğretimsel muhalefetin "etkileyici" alt boyutunda en çok "Dersi daha iyi anlayabilmek için öğretmenimle aynı fikirde olmadığım noktaları ona söylerim" ( $\bar{X}=3,53)$ ifadesine "büyük oranda katıllyorum" düzeyinde, en az ise "En iyi notu alabilmek için öğretmenim ile endişelerimi paylaşırım" ( $\bar{X}=2,98$ ) ifadesine "orta düzeyde katılıyorum" şeklinde görüş belirtmişlerdir. Katılımcllar ilgili alt boyuta $(\bar{X}=3,23)$ "orta düzeyde katılıyorum" şeklinde görüş belirtmişlerdir. Buna göre öğrenciler; dersi daha iyi anlayabilmek için endişe ettikleri veya düzelmesini istedikleri bazı konuları öğretmenlerine ifade etme davranışlarını orta düzeyde sergilemektedirler. Bu durum, lise öğrencilerinin etkileyici mu- 
halefet davranışlarını normal seviyede sergilediklerinin bir göstergesi olarak görülmektedir.

Öğrenciler "intikamcı" alt boyutunda ise en çok "Öğretmenimin kötü uygulamalarını başkalarına anlatarak onu gözden düşürmeye çalışırım ( $\bar{X}=1,90)$ ifadesine "çok az katılıyorum" düzeyinde, en az ise "Sıkıntı çıkararak öğretmenimden intikam almaya çalışırım" $(\bar{X}=1,62)$ ifadesine "hiç katılmıyorum" düzeyinde görüş belirtmişlerdir. Katılımcılar ilgili alt boyuta ( $\bar{X}=1,75)$ "hiç katılmıorum" şeklinde görüş belirtmişlerdir. Öğrenciler; öğretmenlerinin işten atılmasını istemiyor, onları başkalarının gözünde değersiz kılmak için çok az olumsuz propaganda yapıyor ve öğretmenleri hakkında intikamcı duygular beslemeye hiç katılmıyor.

Tablo 6. Disiplin Yaklaşımlan ve Öğretimsel Muhalefetin Boyutları Arasındaki Korelasyon Durumu

\begin{tabular}{lllll}
\hline & & Dişavurumcu & Etkileyici & İntikamc1 \\
\hline \multirow{3}{*}{ Çağdaş } & $\mathrm{r}$ &,- 033 &, $372^{* *}$ &,$- 333^{* *}$ \\
\cline { 2 - 5 } & $\mathrm{p}$ &, 195 &, 000 &, 000 \\
\hline \multirow{3}{*}{ Geleneksel } & $\mathrm{n}$ & 1512 & 1512 & 1512 \\
\cline { 2 - 5 } & $\mathrm{r}$ &, $216^{* *}$ &,$- 164^{* *}$ &, $425^{* *}$ \\
\hline & $\mathrm{p}$ &, 000 &, 000 &, 000 \\
\hline
\end{tabular}

**Korelasyon, 0.05 düzeyinde anlamlıdır.

Tablo 6'da görüldüğü gibi, disiplin yaklaşımının "çağdaş" alt boyutu ile öğretimsel muhalefetin "dışavurumcu" alt boyutu arasında ( $r=-, 033$; $p<, 01)$ negatif yönde, "düşük" düzeyde, "etkileyici" alt boyutu arasında $(r=, 372 ; p<, 01)$ pozitif yönde, "orta" düzeyde ve "intikamc1" alt boyutu arasında $(r=-, 333 ; p<, 01)$ ise negatif yönde, "orta" düzeyde anlamlı bir ilişki bulunmuştur.

Disiplin yaklaşımının "geleneksel" alt boyutu ile öğretimsel muhalefetin "dışavurumcu" alt boyutu arasında $(r=, 216 ; p<, 01)$ pozitif yönde, "düşük" düzeyde, "etkileyici" alt boyutu arasında $(r=-, 164 ; p<, 01)$ negatif yönde, "düşük" düzeyde ve "intikamcı" alt boyutu arasında $(r=, 425$; $p<, 01)$ ise pozitif yönde, "orta" düzeyde anlamlı bir ilişki bulunmuştur.

Lise öğrencilerinin, öğretmenlerin kullandıkları disiplin yaklaşımlarına yönelik algıları ile öğretimsel muhalefetin geneline ilişkin algıları arasındaki ilişki incelendiğinde; Disiplin yaklaşımının "çağdaş" alt boyu- 
tu ile öğretimsel muhalefet arasında $(r=, 008 ; p<, 01)$ pozitif yönde, "düşük" düzeyde bir ilişki; disiplin yaklaşımının "geleneksel" alt boyutu ile öğretimsel muhalefet arasında $(r=, 236 ; p<, 01)$ ise pozitif yönde, "düşük" düzeyde, anlamlı bir ilişki bulunmuştur.

\section{Tartışma}

Araştırmada, öğretmenlerin çağdaş bir disiplin anlayışına sahip oldukları ve nadiren geleneksel yöntemlere başvurdukları görülmektedir. Bu durum lise öğrencilerinin, öğretmenlerini çağdaş disiplin yaklaşımlarını kullanan bireyler olarak gördüklerini ortaya koymaktadır. Disiplin yaklaşımının öğretimsel muhalefet üzerindeki etkisini belirlemek için oluşturulan ve test edilen modele göre; çağdaş disiplin yaklaşımının etkileyici muhalefeti olumlu yönde intikamcı muhalefeti ise negatif yönde etkilediği görülmektedir. Geleneksel disiplin yaklaşımı, dışavurumcu ve intikamcı muhalefeti pozitif yönde anlamlı olarak etkilerken, etkileyici muhalefeti pozitif yönde düşük seviyede anlamlı olarak etkilemektedir. Buna göre öğretmenler, çağdaş disiplin anlayışına uygun davranışları sergilediklerinde öğrenciler intikamca duygular beslemek yerine iletişime dayalı bir tarz benimsemeyi tercih etmektedir. Öğrenciler, öğretmenlerinin anlayışlı bir sınıf lideri olması karşısında herhangi bir sıkıntıyı daha rahat ifade edebilmekte ve muhalefetlerini etkileyici bir şekilde dile getirebilmektedir. Buna karşılık, öğretmenlerin gelenekselci ve öğrencinin duygularını göz ardı eden anlayışı, öğrencilerinin intikamca duygular beslemesine ve öğretmenleri hakkında kara propaganda yapmalarına yol açmaktadır. İnsan, doğası gereği eksik ve kusurları görmeye meyilli bir varlıktır. Bu nedenle anlayışsız bir tavırla geleneksel disiplin davranışları sergilemenin, öğrenciye hem olumsuz propaganda yapma imkânı vereceği hem de intikamca duyguları körüklemeye yol açacağı söylenebilir. Ada ve İnce'nin (2012) çalışmaları bu sonucu desteklemektedir. Buna benzer birtakım araştırmalara göre, disiplin; başkalarını kontrol etmeye dönük geleneksel bir bakışla ele alındığında başarılı olamaz. Bu durum öğrencilerin memnuniyetsizliğini arttırır ve istenmeyen muhalefet biçimine neden olur (Humpreys, 1998, s.17; Demirtaş, 2012: 18; Weishew ve Peng, 1993, s.5-17; Sheets, 2002; Bekiari, Heropoulou ve Sakellariou, 2005; Tor ve Sargin, 2005). 
Katı yani gelenekçi bir disiplin anlayışında, öğretmenlerle öğrenciler arasındaki çatışmaların çoğu, sınıfta güç mücadelesi etrafında döner. Eğer öğretmen baskıcı olmaya çalışırsa, öğrenciler bunu hissedecek ve ona karşı asi bir tutum takınacaklardır. Bu nedenle öğretmenin tutumu, öğrencilerin ne düşündüklerini ve neler hissettiklerini içeren, onlara önem veren bir tutum olmalıdır. Öğretmen, gücü paylaştığında kontrolü kaybedeceğini düşünmemelidir. Paylaşılan güç, sorumluluk ve bunlar arasındaki eşitlik birçok genel disiplin problemlerinin azalmasına katkı sağlayacaktır (Zeiger, 2000; Akt. Demirtaş, 2012, s.18). Öğretmen öğretme-öğrenme etkinliklerini etkili biçimde tasarlayıp uygulayabiliyorsa, öğrencinin yaptığ 1 etkinliklere ve başarısına ilişkin dönüt sağlıyorsa istenmeyen davranışlara daha az rastlanmaktadır (Weishew ve Peng, 1993, s.5-17).

Öğretimsel muhalefete ilişkin bulgular incelendiğinde, öğrencilerin öğretmenleriyle veya dersle ilgili bir sıkıntıyı gideremedikleri durumlarda arkadaşlarına anlatmayı tercih ettikleri görülmektedir. Öğrencilerin muhalefetlerini dişavurmada büyük oranda arkadaşlarıyla paylaşarak ortaya çıkardıkları görülmektedir. Bu durumda öğretimsel muhalefeti uygun yollarla ifade edemeyen öğrencilerin bunu arkadaşlarına anlatarak dışavurmalarının kaçınılmaz olduğu sonucuna varılabilir. Horan ve arkadaşları öğrencilerin \%52,1'inin muhalifliği de kapsayan sınıf içerisinde ortaya çıkan haksızlıklara davranış olarak tepki gösterdiklerini, bu da öğrencilerin adalet algılarının ötesinde muhalifliğe sebep olan sayısız nedenlerin olduğunu ortaya koymaktadır (Goodboy, 2011b). Öğrenciler öğretimsel muhalefetlerini ifade ederken genellikle sınıfla ilgili konularda anlaşmazlık ve şikâyetlerini dile getirirler (Goodboy, 2011a). LaBelle, Martin ve Weber'in (2013) yaptıkları çalışmaya göre, öğretmenler anlaşılır, akıcı, fark edilebilir etkili davranışlar sergilediklerinde ve olumlu bir sınıf ortamı oluşturduklarında öğretimsel muhalefetten vazgeçilmektedir. Öğretimsel muhalefet üzerine yapılan araştırmalar göstermektedir ki öğrencilerin geneli, sınıf şartlarını öğrenciler için istemsiz bir hale getirdiklerinden dolayı öğretmenlerini muhalefetin tek sebebi olarak görmektedir (Bolkan ve Goodboy, 2013; Goodboy, 2011a; Horan, Chory ve Goodboy, 2010). Buna karşılık öğrenciler, hoşnutsuzluklarını dile getirmek için iletişim ihtiyacı hissetmekte ve bu durumu öğretmenlerine muhalefet ederek dışarıya vurmaktadırlar (Goodboy, 2011b). Ayrıca Marzano 
(2003) muhalif çocukların, orta düzeyde davranış sorunları sergilediklerini fakat sıklıkla kurallara uymaya karşı koyabileceklerini, yetişkinlerle tartıştıklarını, kaba bir dil kullandıklarını ve şikâyet etme eğiliminde olduklarını ifade eder (Uyanık Balat, 2013).

Etkileyici muhalefet boyutunda öğrencilerin; dersle ilgili endişelerinin giderilmesinde, öğretmenlerine katılmadıkları noktaları söylemede ve başarılı olmak için ihtiyaç duydukları şeyi öğretmenlerine ifade etmede çekinmedikleri ve büyük oranda bunu yaptıkları görülmektedir. Bu durumda öğretmenlerin, öğrencilerinin derse yönelik düşüncelerine büyük oranda değer verdikleri şeklinde yorumlanabilir. Etkileyici muhalefet, öğretmenle kurulan iletişim ile bir yanlışı düzeltmeye yönelik tek muhalefet türüdür ve bilişsel öğrenmeye pozitif etkisi vardır (Goodboy, 2011a). Cooper ve Sawaf (2010: 141-143), bozucu bir etkisi olmasina karşın muhalefetin, derin bir güven yaratmak ve iletişim kurmak için gereken yaratıcı fikirlerin ve imkânların kaynağı olduğunu belirtmektedir.

Öğretmenler, muhalefeti kötülemek yerine onun değerini ve etkisini anlayarak öğrencileri ve sınıfı için pek çok özel yol bulabilir. Bunlar; farkında olma, problemleri ortaya çıkarma, empati kurma, güven, katılım, yaratıcı işbirliği, daha iyi sonuçlar, eylemle öğrenme, mücadele ve sorumluluk ve zamanı iyi kullanma şeklinde sıralanabilir. Geri bildirimden yoksun öğretmenlerin, herhangi bir öğrenci veya sınıfın geneli ile ilgili var olan bir sıkıntının farkına varmaları ve bunu çözüme kavuşturmaları zor olacaktır.

İntikamcı muhalefet ile ilgili öğrencilerin; öğretmenlerinin kötü uygulamalarını başkalarına anlatarak onları gözden düşürme ve öğretmenlerinin kötü biri olduğunu herkese anlatma davranışını çok az sergiledikleri görülmüştür. Bu da öğretimsel muhalefetlerini ortaya koyarken öğrencilerin, intikamcı bir tutum sergilemekten kaçındıklarını göstermektedir. Bu sonuç ülkemizde Anadolu lisesi öğrencilerinin öğretmenlerle problem yaşama durumunda bile intikamcı muhalefeti çok da tercih etmediklerinin bir göstergesi olarak görülmektedir. Bu durum, öğrencilerin içinde yetiştikleri kültürün; öğretmenler hakkında kötü konuşma, onlara zarar verme, meslektaşlarıyla zor durumda bırakma, kendi mesleğini kaybetmesini sağlama ve onlardan intikam alma gibi konulara sıcak bakmaması şeklinde yorumlanabilir. Chory-Esad ve Paulsel'e (2004) göre, öğrenciler canının yakıldığını hissettiğinde öğretmenlerine 
zarar vermeye yönelik saldırgan ve düşmanca tavırlar içine girebilmektedir. Yükseköğretimdeki öğrencilerin muhalif davranışlarını inceleyen bazı araştırmalarda, muhalefetin büyük ölçüde öğretim elemanlarının davranışlarından kaynaklandığı, öğrencilerin kendilerine yakın davranan öğretim elemanlarına direnç göstermedikleri, buna karşıllı öğrencilerin kendilerine soğuk davranan ve uzak olarak gördükleri, kısaca sevmedikleri öğretim elemanlarına direnç gösterdikleri tespit edilmiştir. Ayrıca araştırmada öğrencilerin öğretmenle açıkça karşı karşıya gelmekten kaçındıkları ve bunu sözel olmayan şekilde gösterdikleri tespit edilmiştir (Plax, Kearney, Downs ve Stewart, 1986).

Eğitim fakültesi öğrencilerinin öğretme-öğrenme süreçlerine yönelik direnç/muhalefet davranışlarını inceleyen Yüksel (2004) direncin/muhalefetin yönetilmesi için şu önerilerde bulunmuştur: Öğretmenler öğrencilerin ait oldukları toplumsal grupların düşünceleri, değerleri ve gelenekleri hakkında bilgi sahibi olmalıdır. Öretme-örenme süreci öğrencilerin görüşleri alınarak, onlarla birlikte plânlanmalıdır. Öretmeörenme süreci sürekli olarak değerlendirilmelidir. Öğretmenler öğrencilerden sürekli dönüt alarak bu dönütler doğrultusunda yanlış ve eksikliklerini gidermelidir. Sınıftaki olumsuz olaylar gereğinden fazla büyütülmemeli ve sert tepkilerden kaçınılmalıdır. Gereğinden fazla gösterilen tepkiler olumsuz davranışların direnç/muhalefet hâlini almasına yol açmaktadır. Direnç gösteren öğrencilerin tekrar direnç göstermelerinin engellenebilmesi için onlarla iletişim kurulmalı, onlarla yakından ilgilenilmelidir. Öğrencilere gördükleri derslerin önemi ve bu derslerin günlük hayattaki yansımaları konusunda ayrıntılı açıklamalar yapılmalıdır.

Öğretmenin öğrencileri küçük düşürücü, aşağılayıcı bir dil kullanması, arkadaşlarının içinde utandırması ya da hakaret etmesi ve olumlu bir dil kullanmaması gibi davranışlar, öğrencinin öğrenmeye karşı olumlu tutum geliştirmesini ve öğrenmeye güdülenmesini azaltarak öğrenmeyi engellemekte, öğrencide düşmanca duygular gelişmesine neden olmakta ve öğrencinin davranışlarını olumsuzlaştırmaktadır (Bekiari, Heropoulou ve Sakellariou, 2005). Tor ve Sargın (2005) tarafından yapılan bir araştırma öğretmenlerin, kulak çekme, cetvel veya sopayla vurma, tokat atma, azarlama, kalem veya başka bir şey fırlatma gibi davranışlara önemli ölçüde başvurduklarını belirlemiştir. Aynı araştırmada "öğretmen tarafından gösterilen şiddete nasıl tepki verirsiniz?" sorusuna öğ- 
rencilerin \% 54.16's1, öğretmenin dersine çalışmayacağını, \%20.83'ünün öğretmenin ders işleyişini bozmaya çalışacağını belirtmişlerdir. Can ve Baksi'nin (2014) araştırmasında, öğrencilerin sınıf içi tutum ve davranışlarının öğretmen davranışlarına bağlı olarak farklılıklar gösterdiği, öğretmenlerin olumsuz öğrenci davranışlarına verdikleri tepkilerin öğrenci tutum ve davranışlarını etkilediği görülmüştür. Öğrencilerin sınıftaki adalet deneyim ve tepkilerini inceleyen nitel bir çalışmada Horan, Chory ve Goodboy (2010) sınıfta yaşanan bir haksızlıktan sonra öğrencilerin en çok kullandığı davranışsal tepkinin öğrenci muhalefeti olduğunu keşfetmişlerdir. Özellikle, Horan'ın örnekleminin \%52,1'i sınıfta bir haksızlık gördüklerinde kendi öğretmenlerine, diğer öğretmenlere, bölüm başkanına, aile bireylerine, arkadaşlara, diğer öğrencilere muhalif olduklarını söylemektedir. Muhalefetin çoğu öğretmenin, davranışlarına açılama getirmesini istemeye ve onu öğrencilerin adil olarak tanımladığı bir davranışta bulunması için ikna etmeye yöneliktir.

Araştırma sonucunda elde edilen bulgulara dayanarak şu önerilerde bulunulabilir:

Öğrencilerin; dersle ilgili endişelerinin giderilmesinde, farklı düşünceleri dile getirmede, öğretmenine katılmadığı noktaları söylemede ve başarılı olmak için ihtiyaç duydukları şeyi öğretmenlerine ifade etmede kararsız kaldıkları görülmektedir. Bu nedenle öğrencilerin uygun bir şekilde muhalefetlerini dile getirebilecekleri, daha iyi anlamak için önerilerde bulunabilecekleri ve anlaşmazlık noktalarını ifade edebilecekleri bir öğrenme kültürünün liselerde yerleşmesi sağlanmalıdır. Bunun için "drama" ve "münazara" gibi ifade becerilerini geliştiren etkinliklerin ögrretmenler tarafından öğrenilmesi ve sınıflarda aktif olarak kullanılmasi gerekir.

Öğretmenler çağdaş disiplin yaklaşımını benimsediklerinde yapıcı muhalefet artmakta, yıkıcı muhalefet azalmaktadır. Öğretmenler geleneksel disiplin yaklaşımın benimsediklerinde ise yıkıcı muhalefet artmakta, yapıcı muhalefet azalmaktadır. Bu durumda öğrencilerin muhalefet etme tarzlarının (yapıcı veya yıkıcı olma) öğretmenlerin sergiledikleri disiplin yaklaşımından etkilendiği görülmektedir. Bu nedenle öğretimsel muhalefetin zararlarını en aza indiren çă̆daş disiplin yaklaşımıyla ilgili öğretmenlere yönelik hizmet içi eğitimler düzenlenmeli ve bu yaklaşımın öğretmenler tarafından benimsenmesi sağlanmalıdır. Bunun 
için çağdaş disiplin yaklaşımlarının başarılı uygulama örneklerinin öğretmenlere paylaşılarak farkındalık artırılmalıdır.

Öğretmenlerin kendilerini sınıfın merkezine alan, sınıf düzeninin ve kurallarının belirleyicisi olduğu şeklindeki geleneksel yaklaşımın değiş̧mesi, öğrenci beklentilerini, gereksinimlerini ve gelişim özelliklerini merkeze alan özgür ve esnek bir sınıf yaşantısı oluşturmaya yönelik çağdaş bir yaklaşım benimsemeleri açısından, sınıf yönetimi ile ilgili bilimsel yayınları izlemeleri yararlı olabilir. 


\title{
EXTENDED ABSTRACT
}

\section{The Relationship between Discipline Approaches of Teachers and Students' Perceptions on Instructional Dissent}

\author{
İsmet Kaya - Hüseyin Fazlı Ergül \\ Dicle University
}

Classroom management refers to activities aimed at realizing an effective education and communication network. In this sense, managing the classroom requires recognizing the variables that affect classroom management. There are many variables that affect classroom management. One of these variables can be expressed as teachers' approaches to discipline. The discipline approach has an important function in increasing the success of the students in the classroom and improving their behavior.

Based on the researchers examined and theoretical explanations, it can be said that two basic components are emphasized in disciplinary approaches. These can be named as the teacher-centered "traditional approach" in which teacher-student relations are overly structured, and the humane, democratic and student-centered "contemporary approach" that uses the power to provide discipline for the benefit of the student.

In a classroom managed with a traditional approach, the teacher tries to align the students with a set of rules that he has prepared and determined, and to ensure that everyone follows these rules to the letter. The teacher wants students to obey the rules and focuses on how to get students to do what they want. In this approach, what the teacher wants is more important than what the student wants. While this approach makes the teacher strict, intrusive and authoritative, it also makes the student an object that is docile, unable to take responsibility and is always ready to cause problems.

Contemporary discipline approach, which is based on the philosophy that the student is valuable as an individual, is also called democratic, humane and positive discipline. Composing classroom rules together, helping students gain good habits, being model, encouraging, appreciat- 
ing, using body language effectively, thinking about the reason behind the behavior, explaining the result of the behavior and making it realize its harms, ignoring the small flaws, using 'I language' instead of 'you language', active listening, making the lesson and the environment enjoyable, teaching problem solving skills, enabling students to correct their own mistakes, parent-teacher-student meetings can be given as examples of contemporary discipline practices.

The relationship between the individual and the environment is the main variable that underlines all the discussions about students' behavior. What shapes this relationship is the cultural structure that includes the beliefs, behavior patterns, value judgments and assumptions of individuals. This cultural structure encompasses a hierarchy starting from the family and then the class and extending to the society. In this sense, in the disciplinary process, it is important how these rules are interpreted and how the practices in the classroom are evaluated by the students in making sense of and defining the classroom rules. One type of these negative reactions, based on classroom experiences, may be in the form of an expression of disagreement with rules and practices, or dissent, also called inconsistency of ideas.

Ideally, the classroom environment refers to an environment that promotes learning and regulates effective and appropriate communication between teacher and student. However, the expectations of the students may not be met by the teacher and this may cause students to dissent in different ways. Students; this form of dissent, in which teachers express their displeasure and complaints about their discipline behavior and other related factors, is called instructional dissent.

Goodboy (2011a), in his studies of the causes and forms of students' dissent, discovered that students use three types of dissent. They are expressive, rhetorical, vengeful dissent. Expressive and vengeful dissent negatively affects students' communication, motivation, affective learning, and perceptions of class justice. Rhetorical dissent, on the other hand, is the only type of dissent to correct a mistake through communication with the teacher and has a positive effect on cognitive learning. In addition, when it is felt that teachers are understanding, students use more rhetorical dissent, less expressive dissent. 
This study aims to develop solutions to the problems that are experienced and emerging in the fields of discipline and instructional dissent. The aim of the study is to examine the relationship between teachers' disciplinary approaches and students' instructional dissent behaviors according to the perceptions of Anatolian high school students.

In this study, it was examined whether the discipline approaches used by teachers significantly predicted high school students' perceptions of instructional dissent. To determine this, predictive research, one of the relational research designs, was used. In order to determine the sample of the research, firstly, the stratified sampling method was used based on the number of students studying in Anatolian high schools in the central districts of Diyarbakır. A total of 1512 scale forms were evaluated.

In the research, it is seen that teachers have a contemporary understanding of discipline and rarely resort to traditional methods. This situation reveals that high school students see their teachers as individuals who use contemporary discipline approaches. According to the model created and tested to determine the effect of disciplinary approach on instructional dissent; It is seen that the contemporary discipline approach affects the rhetorical dissent positively and the vengeful dissent negatively. While the traditional discipline approach positively affects the expressive and vengeful dissent, it affects the rhetorical dissent positively and at a low level. Accordingly, students prefer to adopt a communicative style instead of having vengeful feelings when teachers show behaviors in line with contemporary discipline understanding. Students are able to express any distress more easily and express their dissent in an rhetorical way when their teacher is an understanding class leader. On the other hand, teachers' traditionalist and ignoring student's feelings cause their students to have vengeful feelings and to make black propaganda about their teachers. By nature, human beings are inclined to see deficiencies and flaws. For this reason, it can be said that exhibiting traditional discipline behaviors with an unsympathetic attitude will both give the student the opportunity to make negative propaganda and lead to vengeful feelings.

When the findings regarding the instructional dissent are examined, it is seen that the students prefer to tell their friends when they cannot 
solve a problem with their teacher or the lesson. It is seen that the students reveal their dissent mostly by sharing it with their friends. In this case, it can be concluded that it is inevitable for students who cannot express instructional dissent in appropriate ways to express this by telling their friends.

With rhetorical dissent; it is seen that students do not hesitate to address their concerns about the lesson, tell their teachers about the points they disagree with, and express what they need to be successful, and they do this to a large extent. In this case, it can be interpreted those teachers greatly value their students' thoughts about the lesson.

Instead of vilifying dissent, teachers can find many special ways for their students and class by understanding its value and impact. Those values and impacts are awareness, revealing problems, empathizing, trust, participation, creative cooperation, better results, learning by action, struggle and responsibility, and good use of time. Without feedback, it will be difficult for teachers to recognize and resolve an existing problem with a particular student or class in general.

With vengeful dissent, it has been observed that students show very little behavior of discrediting their teachers by telling others about their bad practices and telling everyone that their teacher is a bad person. This shows that the students avoid displaying a vengeful attitude while revealing their instructional dissent. This result is seen as an indication that Anatolian high school students in our country do not prefer vengeful dissent very much even when they have problems with teachers. This is due to the culture in which the students grew up; It can be interpreted as speaking badly about teachers, harming them, putting them in a difficult situation with their colleagues, making them lose their profession and taking revenge on them.

\section{Kaynakça / References}

Ada, S., ve İnce, B. (2012). Sınıfta istenmeyen davranışlara karşı öğretmenlerin disiplin uygulamalarıyla ilgili ilköğretim 5. Sinıf öğrencilerinin görüşlerinin incelenmesi. Gaziantep University Journal of Social Sciences, 11(4), 1023-1041. 
Akan, D. (2015). Temel kavramlar ve sinıf yönetiminin kapsamı. (Ed: Celal Gülşen). Kuram ve uygulamada sınıf yönetimi. Ankara: Anı Yayıncilık.

Aydın, A. (2014). Sinıf yönetimi. Ankara: Pegem Akademi Yayıncılık.

Aydın, B. (2004). Disiplin sorunları ve çözüm yöntemleri konusunda öğretmen görüşleri. Kuram ve Uygulamada Eğitim Yönetimi, 39, 326-337.

Bal, T. (2005). İlköğretim 4. ve 5. sinıf öğretmenlerinin disiplin anlayışları ve kullandıkları disiplin yöntemleri. Yüksek lisans tezi, Selçuk Üniversitesi, Konya.

Balcı, A. (2015). Sosyal bilimlerde araştırma yöntem, teknik ve ilkeler. Ankara: Pegem Yayıncilik.

Banfield, S. R., Richmond, V. P., ve McCroskey, J. C. (2006). The effect of teacher misbehaviors on teacher credibility and affect for the teacher. Communication Education, 55, 63-72.

Başar, H. (2004). Sinıf yönetimi. Ankara: Anı Yayıncllık.

Bekiari, A., Heropoulou, H. ve Sakellariou, K. (2005). Perceived aggressive physical education teacher communication, student state satisfaction and reasons for discipline. Italian Journal of Sport Sciences, 12(1), 7378.

Bilir, A., Kuru, S., ve Tezcan, F. (2007). Muğla ili ortaöğretim okullarında disiplin uygulamalarına ilişkin yönetici ve öğretmen görüşleri. $M u \breve{g}$ la Üniversitesi Sosyal Bilimler Enstitüsü Dergisi, 1(19), 1-15.

Bolkan, S., ve Goodboy, A. K. (2013). No complain, no gain: Students' organizational, relational, and personal reasons for withholding rhetorical dissent from their college instructors. Communication Education, $62,278-300$.

Büyüköztürk, Ş., Çakmak, E. K., Akgün, Ö. E. Karadeniz, Ş., ve Demirel, F. (2014). Bilimsel araştırma yöntemleri. Ankara: Pegem Akademi Yayınları.

Can, A. (2016). SPSS ile bilimsel araştırma sürecinde nicel veri analizi (4. Baskı). Ankara: Pegem Akademi.

Can, E., ve Baksi, O. (2014). Öğrencilerin sınıf içi tutum ve davranışlarının öğretmenlerin sınıf yönetimi başarısına etkisi. Asya Öğretim Dergisi, 2(1), 86-101.

Celep, C. (2004). Sinıf yönetimi ve disiplin. Ankara: Anı Yayıncılık.

Cheng, Y. C. (2000). Cultural factors in educational effectiveness: A framework for comparative research. School Leadership and Management, 20(2), 207-225. 
Chory-Assad, R. M., ve Paulsel, M. L. (2004). Classroom justice: Student aggression and resistance as reactions to perceived unfairness. Communication Education, 53, 255-275.

Cooper, R. ve Sawaf, A. (2010). Liderlikte duygusal zekâ: Yönetim ve organizasyonlarda duygusal zekâ. (Çev. Zelal Bedriye Ayman ve Banu Sancar), İstanbul: Sistem Yayıncilik.

Çelik, V. (2005). Sinıf yönetimi. Ankara: Nobel Yayın Dağıtım.

Çelikkaleli, Ö., ve İnandı, Y. (2012). İlköğretim öğretmenlerinde disiplin anlayışı ve kişilerarası ilişkiye yönelik yetkinlik inancının incelenmesi. Pegem Ĕ̆itim ve Öğretim Dergisi, 2(2), 15-28.

Dağlı, A. Ergül, H. F., ve Kaya, İ. (2017). Öğretimsel muhalefet ölçeğinin Türkçe'ye uyarlanması: Geçerlik ve güvenirlik çalışması. Akademik Sosyal Araştırmalar Dergisi, 5(50), 237-251.

Demirtaş, H. (2012). "Sınıf yönetiminin temelleri”. (Ed: Hüseyin Kıran). Etkili sinıf yönetimi. Ankara: Anı Yayıncilık.

Durukan, H. (2005). Sinıf yönetimi. (2. Bs.). Ankara: Lisans Yayıncllı.

Goodboy, A. K., ve Bolkan, S. (2009). College teacher misbehaviors: Direct and indirect effects onstudent communication behavior and traditional learning outcomes. Western Journal of Communication, 73, 204219.

Goodboy, A. K., Myers, S. A., ve Bolkan, S. (2010). Student motives for communicating with instructors as a function of perceived instructor misbehaviors. Communication Research Reports, 27, 11-19.

Goodboy, A. K. (2011a). The development and validation of the instructional dissent scale. Communication Education, 60, 422-430.

Goodboy, A. K. (2011b). Instructional dissent in the college classroom. Communication Education, 60, 296-313.

Goodboy, A. K., ve Martin, M. M. (2014). Student temperament and motives as predictors of instructional dissent. Learning and Individual Differences, 32, 266-272.

Horan, S. M., Chory, R. M., ve Goodboy, A. K. (2010). Understanding students' classroom justice experiences and responses. Communication Education, 59, 453-474.

Humpreys, T. (1998). Disiplin, nedir? ne değildir?. (Çev: Berat Çelik), İstanbul: Epilson Yayıncilik.

Karasar, N. (2005). Bilimsel araştırma yöntemi (15. baskı). Ankara: Nobel Yayın Dağıtım. 
Kassing, J. W. (1997). Articulating, antagonizing, and displacing: A model of employee dissent. Communication Studies, 48(4), 311-332.

Kaya, İ., Ergül, H. F., ve Aküzüm, C. (2018). Disiplin yaklaşımları ölçeği: Geçerlik ve güvenirlik çalışması. Social Sciences Studies Journal, 4(21), 3434-3445.

Kılbaş Köktaş, Ş. (2003). Sınıf yönetimi. Adana: Nobel Kitabevi.

Kızılkaya, E. (2006). İlköğretim okulu öğretmenlerinin olumlu disiplin yöntemlerini öğrenme ihtiyacı. Yayımlanmamış yüksek lisans tezi, Uludağ Üniversitesi, Sosyal Bilimler Enstitüsü, Bursa.

LaBelle, S., Martin, M. M., ve Weber, K. (2013). Instructional dissent in the college classroom: Using the instructional beliefs model as a framework. Communication Education, 62, 169-190.

Neff, K. D., ve Helwig, C. C. (2002). A constructivist approach to understanding the development of reasoning about rights and authority within cultural contexts. Cognitive Development, 17, 1429-50.

Plax, T. G., Kearney, P., Downs, T. M. ve Stewart, R.A. (1986). College student resistance toward teachers use of selective control strategies. Communication Research Reports, 3, 20-27.

Saban, A. (2000). Öğrenme-öğretme süreci yeni teori ve yaklaşımları. Ankara: Nobel Yayıncilik.

Sağnak, M. (2007). İlköğretim okullarında ve liselerde kullanılan sınıf içi disiplin stratejilerinin karşılaştırılması. Sosyal Bilimler Enstitüsü Dergisi, 23(2), 305-316.

Sarıtaş, M. (2000). Sınıf yönetimi ve disiplin ile ilgili kurallar geliştirme ve uygulama. (Ed: Leyla Küçükahmet). Sınıf yönetiminde yeni yaklaşımlar. Ankara: Nobel Yayın Dağıtım.

Sesli, S., ve Bozgeyikli, H. (2015). Okul öncesi öğretmenlerinin problem çözme becerileri ile disiplin anlayışlarının incelenmesi. OPUSTürkiye Sosyal Politika ve Çalışma Hayatı Araştırmalar Dergisi, 5(8), 82111.

Şimşek, Ö. F. (2000). Bir grup rehberliği programının öğretmenlerin disiplin anlayışına etkisi. Yüksek lisans tezi, Ankara Üniversitesi, Ankara.

Thweatt, K. S., ve McCroskey, J. C. (1998). The impact of teacher immediacy and misbehaviors on teacher credibility. Communication Education, $47,348-358$.

Tor, H. ve Sargın, N. (2005). İlköğretim okullarının ikinci kademesinde okuyan öğrencilerin şiddet hakkındaki görüşleri. On Dördüncü Ulusal 
Eğitim Bilimleri Kongresi, Pamukkale Üniversitesi Eğitim Fakültesi, Denizli, (28-30 Eylül).

Uslu, A. (2002). Yüzüncü yıl üniversitesinde sını atmosferinin öğrenci başarısına etkisi. Yayımlanmamış yüksek lisans tezi, Ankara Üniversitesi, Ankara.

Ünal, S. ve Ada, S. (2000). Sinıf yönetimi. İstanbul: Marmara Üniversitesi Teknik Eğitim Fakültesi.

Vallade, J. I., ve Myers, S. A. (2014). Student forgiveness in the college classroom: Perceived instructor misbehaviors as relational transgressions. Communication Quarterly, 62, 342-356.

Yıldırım, A. ve Şimşek, H. (2005). Sosyal bilimlerde nitel araştırma yöntemleri. Ankara: Seçkin Yayıncllık.

Yüksel, S. (2004). Eğitim fakültesi öğrencilerinin öğretme-öğrenme süreçlerine yönelik direnç davranışları. Türk Eğitim Bilimleri Dergisi, 2(3), 341354.

Wanzer, M. B., ve McCroskey, J. C. (1998). Teacher socio-communicative style as a correlate of student affect toward teacher and course material. Communication Education, 47, 43-52.

Weishew, N. L. ve Peng, S. S. (1993).Variables predicting students' problem behaviors. Journal of Educational Research, 87(1), 179-215.

\section{Kaynakça Bilgisi / Citation Information}

Kaya, İ. ve Ergül, H. F. (2021). Öğretmenlerin disiplini sağlama yaklaşımları ile öğrencilerin öğretimsel muhalefet davranışları arasındaki ilişkinin incelenmesi. OPUS-Uluslararası Toplum Araştırmaları Dergisi, 18(40), 2116-2145. DOI: 10.26466/opus.855051. 